\title{
Mõningad märkused nelja ilmakaare kuninga ja jumal-kuninga kontseptsiooni kohta Sumeris ja Akkadis 3. at eKr
}

\author{
Vladimir Sazonov \\ Tartu Ülikooli Vana-Lähis-Ida uuringute vanemteadur, \\ Eesti Kaitseväe Akadeemia vanemteadur, \\ Sisekaitseakadeemia teadur \\ sazonov@ut.ee
}

\begin{abstract}
Teesid: Käesolev artikkel on pühendatud nelja ilmakaare kuninga ja jumalkuninga kontseptsioonile muistses Sumeris ja Akkadis kolmandal aastatuhandel eKr. Autor näitab artiklis, et tiitliga "nelja ilmakaare kuningas" oli valitseja alati jumalikustatud, kuid valitseja, kes kasutas tiitlit "maailma kuningas", ei pretendeerinud mitte kunagi jumalikule staatusele.
\end{abstract}

Märksõnad: Akkad, jumalikustamine, jumal-kuningas, Mesopotaamia, nelja ilmakaare kuningas, Sumer, universumi kuningas

\section{Sissejuhatavad märkused}

Nagu käesoleva artikli autor on näidanud oma varasemates uurimustes (Sazonov 2015; Sazonov 2016a; Sazonov 2018; Sazonov 2019), olid universalistlikud tendentsid ja kuningate jumalikustamine muistses Mesopotaamias omavahel tihedalt seotud. Kuningate jumalikustamist, nende jumalikku staatust, päritolu ning universalistlikke epiteete ja tiitleid on uurinud mitmed teadlased (Seux 1965; Seux 1967; Emelianov 2008; Michalowski 2008; Bock 2012; Brisch 2006; Brisch 2013; Edzard 1974; Farber 1983; Maeda 1981; Maeda 1984; Selz 1998; Selz 2008). Samas on seoseid universalismi ja jumalikustamise vahel assürioloogias uuritud üpris vähe.

Käesoleva artikli autor väidab, et peaaegu kõik Sumeri ja Akkadi valitsejad alates Narām-Su'enist kuni 3. aastatuhande lõpuni ja isegi hiljem (nt mõned Isini kuningad, nagu Išme-Dagan ${ }^{1}$ ), kes kasutasid tiitlit nelja ilmakaare kuniningas - šar kibrāt arba’i (m) (Maeda 1984; Sazonov 2016b: 73-76), olid juba eluajal jumalikustatud. Valitsejaid, kes kasutasid teist olulist universalistlikku tiitlit maailma kuningas ( $\check{a r}$ kiššati $(m)=$ LUGAL KIŠ), ${ }^{2}$ mille oli sisse viinud 
Sargon (2334-2279 eKr) Akkadi ajastu alguses (RIME 1: Me-silim E1.8.1.3, p. 71, read 1-4), ei jumalikustatud mitte kunagi. ${ }^{3}$

Oluline on märkida, et tiitlit nelja ilmakaare kuningas kasutati vahel ka Mesopotaamia jumalate puhul - nt jumal Tišpakit Ešnunna linnast (RIME 3/2: Šū-ilìia E3/2.3.1, read 4-6) nimetati nelja ilmakaare kuningaks. Kuid mitte ühtegi jumalat Mesopotaamias ei ole kunagi nimetatud maailma kuningaks, mis ilmselt tähendab seda, et sellel tiitlil oli jumalik aspekt, ja selle tiitli sumerikeelne versioon lugal an-ubda-limmuba tähendas "taeva nelja ilmakaare kuningas" (Michalowski 2010: 153). Seega jääb mulje, et selle tiitli kandja oli ühtlasi seotud ka taevase valitsemisega, universumi valitsemisega, päikese, kosmose, tähtede ja kosmiliste jumalike jõududega.

\section{Akkad}

Piotr Michalowski on teinud huvitava tähelepaneku, et Akkadi kuningate ${ }^{4}$ võimu all oli Mesopotaamia poliitiliselt transformeeritud, Akkadi kuningad mõistsid, et pole olemas geograafilisi piire ning laiendasid oma riiki maa lõpuni ehk piirini, mida nad teadsid, viies oma sõjakäike nii Iraani kui ka Põhja-Mesopotaamiasse, jõudes Vahemereni, kus nad pesid oma relvi (Michalowski 2010: 152). Akkadi neljas kuningas Narām-Su'en (2254-2218 eKr) (RIME 2: 84-181) oli ajaloos esimene, kelle ajal võeti kuninga ametliku tiitlina käibele universalistlik tiitel nelja ilmakaare kuningas (RIME 2: 174; RIME 2: Narām-Sîn E2.1.4.1 ja RIME 2: Narām-Sîn E2.1.4.4). Just Narām-Su'en võttis esimesena kasutusele selle universalistliku tiitli, kehtestades samal ajal ka enda isikukultuse ja jumalikustamise (vt jumalikustamise kohta Farber 1983; Sazonov 2007; Sazonov 2016a) - ${ }^{\mathrm{d}} n a-r a-a m$ - ${ }^{\mathrm{d}} \mathrm{EN} . Z U$ da-núm LUGAL ki-ibra-tim ar-baim - "Narām-Su'en, võimas kuningas, nelja ilma kaare kuningas" (RIME 2: Narām-Sîn E2.1.4.2006, read 1-5).

Ajastut, mis järgnes Narām-Su'eni surmale, käsitletakse tavaliselt kui Akkadi impeeriumi allakäigu ajajärku, mil see riik nõrgnes, kaotas suure hulga territooriume võõrvallutajatest gutilastele ja hävis lõplikult umbkaudu aastal 2154 eKr, kui gutilased, kes elasid Zagrose mägedes, vallutasid nõrgenenud Akkadi riigi jäänused. See allkäik algas Narām-Su'eni järglase Šar-kali-šarrī ajal, kes valitses aastail 2217-2193 eKr. Aage Westenholzi väitel loobus Šar-kali-šarrī kohe ambitsioossest programmist, mida alustas tema isa, ega kasutanud kunagi tiitlit nelja ilmakaare kuningas, samuti loobus ta enda isiku jumalikustamisest (OBO 160/3: 56). 
Ma ei saa selle ideega nõustuda ja olen seda ka varasemates uuringutes ümber lükanud (Sazonov 2007; 2016; 2019). Olen jätkuvalt arvamusel, et kuigi Šar-kali-šarrī ei kasutanud enam tiitlit nelja ilmakaare kuningas, oli ta siiski lühikest aega jumalikustatud (Sazonov 2007: 333-337; Sazonov 2016a: 50-52). Veelgi enam: ta taotles endale sumerlaste ja akkadlaste peajumala Enlili poja staatust, ehk siis tahtis, et teda samastataks sõjaka kangelasjumala Ninurtaga (FAOS 7: 114-115; RIME 2: Šar-kali-šarrī E2.1.5.2, lk 188-189), nagu hiljem mitmeid Ur III ja Isini valitsejaid, nt Lipit-Eštar (1935-1924 eKr) (Sazonov 2007: 333-337; Sazonov 2016a: 50-52; Emelianov 2008: 135; Emelianov 2009: 276; Simkó 2013: 117). Igal juhul kohe oma valitsemise alguses Šar-kali-šarrī loobus või oli sunnitud loobuma tiitlist nelja ilmakaare kuningas, mille oli enesele võtnud Narām-Su'en.

\section{Gutilaste ajastu}

Ainult üks gutilaste valitseja - Erridu-pizir, kes oletatavasti oli võidukas mingis sõjalises aktsioonis (nt lahingus) Akkadi kuninga üle, võttis üle tiitli nelja ilmakaare valitseja (RIME 2: Erridu-pizir E2.2.1.1, read 17-18).

Samas ei leidu mitte ühtegi tõendit või vihjet selle kohta, et mõnda guti kuningat oleks jumalikustatud, kuigi välistada seda ei saa, sest gutilaste kuningatest on säilinud liiga napilt kuninglikke raidkirju. Kuid siiski, kui ühtki guti valitsejat ei jumalikustatud ja Erridu-pizir kasutas tiitlit nelja ilmakaare valitseja, tähendab see vaid seda, et tegu on erandiga, mis ei sobi paradigmasse JUMALVALITSEJA - NELJA ILMAKAARE KUNINGAS. Ei tasu unustada, et gutilased ei olnud kuigi hästi kursis Mesopotaamia traditsioonidega, sh kuningavõimu ideoloogiaga, kuna nad olid tulnud Zagrosest ja olid võõramaalased. Miks vaid Erridu-pizir otsustas ainsana guti valitsejatest seda tiitlit kasutada (akkadi k LUGAL gu-ti-im ù ki-ib-ra-tim ar-ba-im - Gutiumi ja nelja ilmakaare kuningas), ei ole selge, kuid võib oletada, et kuna ta oli võidukas Akkadi kuninga üle, võttiski ta ülemvalitseja rolli enda kätte ja toonitas, et hoopis tema on Akkadi impeeriumi valitseja legitiimne järeltulija ning nagu Peeter Espak on õigesti märkinud: "Gutilastel ei olnud omaenda suurt tsentraliseeritud impeeriumi, kuid vähemalt üks nende valitseja Erridu-pizir kasutab oma titulatuuris lisaks Gutiumi kuninga nimetusele veel ka "nelja (ilma)kaare kuninga" tiitlit: LUGAL gu-ti-im ù ki-ib-ra-tim ar-ba-im. Sellest võib järeldada, et osad gutilaste väepealikud pidasid ennast Akkadi impeeriumi valitsejatega vähemalt ideoloogia tasandil võrdseks ning pretendeerisid seega legitiimse Mesopotaamia kuninga positsioonile” (Espak 2013: 8). 


\section{Uruk V}

Uus-Sumeri ajastust (Uruk V, Ur III) on meil mitmeid valitsejaid, kes võtsid uuesti kasutusele tiitli nelja ilmakaare kuningas - Utu-heĝal, Šulgi, AmarSu'ena jt. Esimene Uus-Sumeri ajastu kuningas, kes selle tiitli "taastas" oli Utu-ḩeĝal (Uruk V dünastia, valitses 2119-2012 eKr või hiljem), kelle peamine saavutus oli see, et ta oli sõjas võidukas gutilaste (Espak 2015: 80-86) üle ja ajas nad Mesopotaamiast minema, vallutades "tagasi" Sumeri ja Akkadi. Seejärel võttis Utu-ḩeĝal endale tiitli nelja ilmakaare kuningas. Siiski pole otseseid tõendeid, et Utu-hegal oli jumalikustatud, kuigi ta kasutas tiitlit nelja ilmakaare kuningas (RIME 2: 281, 283, 294, 295, 296; The victory of Utu-hegal, ETCSL c.2.1.6; rida 11) ega kasutanud mitte kunagi tiitlit maailma kuningas.

Utu-heĝali jumalikustamine on küsimärgi all, sest selle kohta pole leitud otsest kinnitust, ja Utu-ḩegali nime ees seisev jumalikustamist tähistav determinatiiv “dingir" ei pruugi kuuluda Utu-heĝali nime juurde, vaid hoopis päikesejumal Utule, sest Utu-ḩeĝali nimi on teofoorne ja tähendab '(päikesejumal) Utu (on minu) küllus' (Sazonov \& Espak \& Johandi 2015: 141).

Kuna Utu-heĝal esineb jumalikustamise märgiga ehk determinatiiviga dingir (jumal) - ${ }^{\mathrm{d}}$ utu-he ${ }_{2}$-ga-al ${ }_{2}$, siis võib oletada, et Uus-Sumeri kuningate jumalikustamine võib ajas tagasi ulatuda juba Utu-heĝalini. Tema eeskujul hakkasid ka teised Uus-Sumeri valitsejad (Ur-Namma, Šulgi jt) kasutama tiitlit nelja ilmakaare kuningas, tõstes sellega esile, et nad on kogu universumi valitsejad. Sumerikeelses kirjanduslikus teoses "Poeem Utu-ḩeĝalist" märgitakse kuningas Utu-ḩeĝal ära kui "nelja ilmakaare kuningas", kuid see tiitel on tõlgitud akkadi keelest sumeri keelde ning kõlab järgmiselt: (read 10-11):

${ }^{\mathrm{d}}$ utu-he ${ }_{2}$-ga-al ${ }_{2}$ nita kalag-ga lugal unugki-ga lugal an-ub-da 4(ZA)-ba lugal dug ${ }_{4}$-ga-na $n u-g i_{4}-g i_{4}-d a$ (ETCSL c 2.1.6; vt ka RIME 2: Utu-hegal E2.13,6.1, read 4-5) - [(jumalik?) Utu-heĝal, võimas mees, Uruki kuningas, nelja ilmakaare kuningas, kuningas, kelle käske ei saa tühistada].

\section{Ur III}

Mitte ükski Ur III (2112-2004) (Espak 2016) valitseja ei kasutanud tiitlit šar kiššati(m) - maailma kuningas. Selle dünastia teine valitseja Šulgi (2093-2046 eKr) (Klein 1995; Di Ludovico 2014) viis uuesti sisse valitseja jumalikustamise, ${ }^{5}$ ning alates Šulgist olid kõik ülejäänud Ur III kuningad jumalikustatud nende eluajal ning Šulgi Amar-Su'ena, Šu-Su'en ja Ibbi-Su'en olid kõik ka nelja 
ilmakaare kuningad. ${ }^{6}$ Šulgit oli mitmes tekstis nimetatud jumalikuks, samuti oli tema kohta kasutatud ka tiitlit nelja ilmakaare kuningas, nagu nt "Uri ja nelja ilmakaare kuningas" - LUGAL URI .KI ù LUGAL ki-ib-ra-tim ar-ba-im (RIME 3/2: Šulgi E3/2 1.2.23, S. 132, read 3-6; vt ka Ur 2 (Šulgi 4) (FAOS 7: 339-340), Ur 3 (Š́ulgi 14) (FAOS 7: 340), Ur 4 (Šulgi 36) (FAOS 7: 341)). Šulgi ajal tõusis esile kuningavõimu solaarne aspekt (Vacín 2009: 171-179).

Šulgi ja tema järglase Amar-Su'ena kuningluse solaarne aspekt on selgesti nähtav ka uus-sumeri tekstides, nt ühes Šulgile pühendatud hümnis (Šulgi C, read 25-27) on kirjas järgmine väide, mida Šulgi ise olevat enda kohta öelnud:

Ma tõusin üle mu linna nagu päikesejumal Utu, peatusin selle keskel, ma täitsin vürstliku karneooliga Etemenniguru mis oli rajatud jumalike jõudude poolt. (A praise poem of Šulgi ( ̌́ulgi C), ETCSL translation: t.2.4.2.03)

Šulgi järglane ja poeg kuningas Amar-Su'ena jätkas oma isa traditsiooni ning nimetas ennast mh ka "õige jumal, oma maa päikesejumal" (dingir-zi ${ }^{\mathrm{d} u t u-}$ kalam-ma-na) (RIME 3/2 Amar-Suena E3/2.1.3.16, p. 263, read 10-11).

\section{Isin}

Teame, et Isini I dünastia kuningad olid jumalikustatud ja nagu Narām-Su'en, Šulgi, Amar-Sue'na ja teised, kasutasid nad oma nime eest jumalikustamise klassifikaatorit ehk determinatiivi dingir ("jumal, jumalik"), ja mõned neist kasutasid tiitlit "oma rahva/maa jumal" - dingir-kalam-ma-na. ${ }^{7}$ Näiteks esimesed neli Isini kuningat - Išbi-Erra, Su-ilî̌su, Iddin-Dagan ja Išme-Dagan olid kõik jumalikustatud oma eluajal, keegi neist ei kasutanud kunagi kuninglikku tiitlit universumi kuningas, kuid vähemalt kaks neist, Išbi-Erra ja Išme-Dagan, kasutasid tiitlit nelja ilmakaare kuningas. ${ }^{8}$ Näiteks Išbi-Erra alustas ühes raidkirjas (RIME 4: Išbi-Erra E4.1.1.2006, read 1-3) oma titulatuuri sumeri keeles järgmiselt: ${ }^{\mathrm{d}}[i \check{s}$-bi-èr]-ra lugal-kala-ga lugal-an-ub-da-límmu-ba [Išbi-Erra, võimas kuningas, nelja ilmakaare kuningas]. Teine Isini valitseja Išme-Dagān kasutas oma raidkirjas (RIME 4: Išme-Dagān E4.1.4.5, read 1-4) ka sumerikeelses titulatuuris varianti: ${ }^{\mathrm{d}} i \check{s}^{-}-m e-{ }^{\mathrm{d}} d a$-gan nita-kala-ga lugal-ì-sinin $^{\mathrm{ki}}$-na lugal-an-ub-da-límmu-ba-ke ${ }_{4}$ [Išme-Dagān, võimas mees, Isini kuningas, nelja ilmakaare kuningas]. 


\section{Järeldused}

Mida me saame järeldada? Kui jätta kõrvale kaks juhtumit - Erri-dupizir ja Utu-ḩeĝal -, olid jumalikustatud kõik valitsejad, kes nimetasid ennast nelja ilmakaare kuningaks.

Erri-dupizirist on säilinud üksikud raidkirjad, seega ei saa välistada, et ta võis olla jumalikustatud, samas oli ta võõramaalane ja pigem hõimupealik kui kuningas, sest gutilastel oli hõimulaadne eluviis. Üritades saada legitiimsust ja tunnustust võttiski Erri-dupizir ilmselt üle nii Akkadi-Sumeri raidkirjade vormi, akkadi keele kui administratsiooni keele, samuti kõik Akkadi kuninga tiitlid. Utu-ḩegal (2119-2012 eKr või hiljem) vabastas Sumeri gutilaste ikkest ning taastas vanad Sumeri ja Akkadi ideoloogia traditsioonid, sh Akkadi kuninga Narām-Su'eni tiitli nelja ilmakaare kuningas. Kuna Utu-ḩeĝal valitses kuus-seitse aastat ja temast on säilinud vaid üksikud raidkirjad, ei saa me tema jumalikustamise kohta midagi järeldada.

Palju olulisem on ehk asjaolu, et mitte ükski Sumeri ja Akkadi kuningatest ning isegi teisel Kristuse-eelsel aastatuhandel valitsenud Isini kuningad, kes olid jumalikustatud, ei kasutanud kunagi universalistlikku tiitlit universumi kuningas. Kuidas sellist fenomeni seletada?

Võib järeldada, et kuigi tiitlid nelja ilmakaare kuningas ja universumi kuningas olid mõlemad universalistlikud ning mõlemat kasutasid auahned kuningad, kelle soov oli kontrollida ja valitseda tervet toona teadaolevat maad, erinesid need tiitlid siiski oma tähenduse poolest. Nelja ilmakaare kuningas oli arvatavasti tähtsam, kuna see sisaldas mitte ainult kogu teadaoleva maailma valitsemist, vaid ka kosmilist valitsemist, jumalikke sfääre nagu taevas, päike, kuu, tähed jne, selle sumerikeelne versioon lugal an-ubda-limmuba tähendas mitte juhuslikult "taeva nelja ilmakaare kuningat" ehk tegemist oli kosmokraatliku valitsejaga. Maailma kuningas oli selles mõttes "lokaalsem" ja "tagasihoidlikum", sest selle valitseja valitses maapealset maailma, polnud seotud kosmokraatliku kontseptsiooniga, algselt selle sumerikeelne versioon LUGAL KIŠ tähendas üldse põhja Sumeris asuva Kiši linnriigi valitsejat/kuningat, mis hiljem muutus oluliseks hegemoniaalseks tiitliks tähendusega "kogu Põhja-Sumeri valitseja” ja hiljem kui universumi kontseptsioon muutus Akkadi impeeriumi ekspansiooniga ning maailma piirid laienesid, tõlkis Akkadi kuningas Sargon LUGAL KIŠ akkadi keelde kui šar kiššati(m)), mis hakkaski tähendama "maailma/universumi kuningat".

Universum oli muidugi toonases arusaamas kogu Sumer ja Akkad ning lisaks nendega piirnevad alad nagu Elam, Süüria linnriigid - sisuliselt hakkas see tähendama kogu Mesopotaamia alasid Vahemerest Pärsia laheni ning veel 
mõningaid Mesopotaamiaga piirnevaid territooriume. Seega isegi pärast Akkadi kuningaid hakkas tiitel LUGAL KIŠ tähendama geograafilist tiitlit, millel olid siiski piirid, kuigi see omandas universalistliku dimensiooni.

\section{Kommentaarid}

1 Valitses 1954-1935 eKr. Siin ja hiljem kasutab autor keskmist kronoloogiat. Kronoloogiate kohta vt Sazonov \& Espak \& Johandi 2015: 42-43.

2 Maeda 1981. LUGAL KIŠ oli tiitlina tuntud juba varadünastilisel ajal Sumeris, kuid seda kasutasid kas Kiši linnriigi valitsejad või siis teiste Sumeri linnriikide valitsejad "Põhja-Sumeri linnade (ülemvalitseja)" tähenduses.

3 Sargon, Rimuš, Man-ištūšu ja teised 3. eelkristliku aastatuhande valitsejad, kes kasutasid tiitlit maailma kuningas.

4 Akkadi ajastu oli Mesopotaamias aastail 2334-2154 eKr.

5 Vt Šulgi jumalikustamise kohta Sazonov 2008; Vacín 2011.

6 RIME 3/2: p. 247, 258, 259, 260, 302, 309, 313, 315, 369, 372, 374, 377, 380, 381; Garelli (1963: 2): d $I$-[b]i-d.EN-zu lugal kala(g)-ga lu[gal] Urí[ki-ma] [lugal an-]ub-[da limmu]-ba Ur-d.Lugal-bànda dub-sar dumu Ur-nigìn-gar ìr-zu.

7 Vt nt RIME 4: Išbi-Erra E4.1.1.2009, 1. 2; RIME 4: Sū-ilîšs E4.1.2.2, 1. 4.

8 RIME 4: Išbi-Erra E4.1.1.2006, rida 3; RIME 4: Išme-Dagan E4.1.4.1 32, 1. 4.

9 RIME 1: Lugal-kiğine-dudu E1.14.14.1, p. 414, read 1-8.

\section{Kirjandus}

Brisch, Nicole 2006. The Priestess and the King. The Divine Kingship of Šu-Sîn of Ur. Journal of the American Oriental Society 126/2, lk 161-176.

Brisch, Nicole 2013. Of Gods and Kings: Divine Kingship in Ancient Mesopotamia. Religion Compass 7/2, lk 37-46 (doi: 0.1111/rec3.12031).

Bock, Ulrike 2012. Von seiner Kindheit bis zum Erwachsenenalter. Die Darstellung der Kindheit des Herrschers in mesopotamischen und kleinasiatischen Herrscherinschriften und literarischen Texte. AOAT 383. Münster: Ugarit-Verlag.

Edzard, Dietz-Otto 1974. Problèmes de la royauteé dans la période présargonique. Garelli, Paul (toim). Le Palais er la Royauté (Archéologie et Civilisation). XIXe Recontre Assyriologique Internationale, organisée par le grupe François Thureau-Dangin, Paris, 29 juin - 2 juillet 1971, Librairie Orientaliste Pual Geuthner S.A., Paris, lk 141-149.

Espak, Peeter 2013. Sumeri vabastaja kuningas Utu-hegal, jumaliku õigluse taastaja. Tuna 2013/2, lk 7-15. 
Espak, Peeter 2015. The God Enki in Sumerian Royal Ideology and Mythology. Philippika: Altertumswissenschaftliche Abhandlungen: Contributions to the Study of Ancient World Cultures Wiesbaden: Harrassowitz.

Espak, Peeter 2016. The Esthablishment of Ur III Dynasty. From the Gutians to the Formation of the Neo-Sumerian Imperial Ideology and Pantheon. Alter Orient und Altes Testament 390/4, lk 77-108.

Emelianov, Vladimir V. 2008. Tsar' kak Ninurta v shumerskikh gimnakh iz Ura i Isina. Rezvan, M. E. (vastutav toim). Rakhmat-name: Sbornik statei $k$ 70-letiiu R. R. Rakhimova. Elektronnaya biblioteka Muzeya antropologii i etnografii im. Petra Velikogo (Kunstkamera). Sankt-Peterburg: MAE RAN, lk 130-143 (http://lib. kunstkamera.ru/files/lib/978-5-55431-158-9/978-5-55431-158-9_08.pdf-22.juuli 2020).

Emelianov, Vladimir V. 2009. Shumerskii kalendarnyi ritual. Kategoriia ME i vesennie prazdniki. Sankt-Peterburg: Peterburgskoe vostokovedenie.

ETCSL = Black, Jeremy A. \& Cunningham, Graham \& Ebeling, Jarle \& FlückigerHawker, Esther \& Robson, Eleanor \& Taylor, Jon \& Zólyomi, Gábor (koost \& toim). The Electronic Text Corpus of Sumerian Literature. Oxford 1998 (http://etcsl.orinst.ox.ac. $\mathrm{uk} /$ - 22. juuli 2020).

Garelli, Paul 1963. Les Assyriens en Cappadoce. Paris: Maisonneuve.

FAOS 7 = Gelb, Ignace J. \& Kienast, Burkhart 1990. Die altakkadischen Königsinschriften des dritten Jahrtausends v. Chr. Freiburger Altorientalische Studien 7. Stuttgart: Franz Steiner Verlag.

Farber, Walter 1983. Die Vergöttlichung Narāmsins. Orientalia NS 52, lk 67-72.

Klein, Jacob 1995. Shulgi of Ur: King of a Neo-Sumerian Empire. Sasson, Jack M. (toim). Civilizations of the Ancient Near East. New York: Scribner, lk 843-857.

Di Ludovico, Alessandro 2014. The Reign of Šulgi. Investigation of a King Above Suspicion. Neumann, Hans \& Dittmann, Reinhard \& Paulus, Susanne \& Neumann, Georg (toim). Krieg und Frieden im Alten Vorderasien. 52e Rencontre Assyriologique Internationale International Congress of Assyriology and Near Eastern Archaeology Munster, 17.-21. Juli 2006. AOAT 401. Munster: Ugarit-Verlag, lk 481-493.

Maeda, Tohru 1981. "King of Kish" in Pre-Sargonic Sumer. Orient 17, lk 1-17 (https:// www.jstage.jst.go.jp/article/orient1960/17/0/17_0_1/_pdf - 22. juuli 2020).

Maeda, Tohru 1984 "King of The Four Regions" in the Dynasty of Akkade. Orient 20, lk 67-82 (doi: 10.5356/orient1960.20.67).

Michalowski, Piotr 2008. The Mortal Kings of Ur: A Short Century of Divine Rule in Ancient Mesopotamia. Brisch, Nicole (toim). Religion and Power: Divine Kingship in the Ancient World and Beyond. Chicago: The Oriental Institute of the University of Chicago, lk 33-45.

Michalowski, Piotr 2010. Masters of the Four Corners of the Heavens: Views of the Universe in Early Mesopotamian Writings. Raaflaub, Kurt A. \& Talbert, Richard J. A. (toim). Geography and Ethnography. The Ancient World: Comparative Histories. Wiley-Blackwell, lk 147-168 (doi: 10.1002/9781444315653.ch10). 
OBO 160/3 = Sallaberger, Walther \& Westenholz, Aage 1999. Mesopotamien: Akkade-Zeit und Ur III-Zeit. Orbis Biblicus et Orientalis 160/3. Freiburg, Schweiz: Universitatsverlag.

RIME 1 = Frayne, Douglas R. 2008. Presargonic Period (2700-2350 BC). The Royal Inscriptions of Mesopotamia: Early Periods, Vol. 1. Toronto - Buffalo - London: University of Toronto Press.

RIME 2 = Frayne, Douglas R. 1993. Sargonic and Gutian Periods (2334-2113 BC). The Royal Inscriptions of Mesopotamia, Early Periods, Vol. 2. Toronto - Buffalo - London: University of Toronto Press.

RIME 3/1 = Edzard, Ditz-Otto 1997. Gudea and His Dynasty. The Royal Inscriptions of Mesopotamia. Early Periods, Vol. 3/1. Toronto-Buffalo-London: University of Toronto Press.

RIME 3/2 = Frayne, Douglas R. 1997. Ur III Period (2112-2004 BC). The Royal Inscriptions of Mesopotamia, Early Periods, Vol. 3/2, University of Toronto Press, TorontoBuffalo-London.

RIME 4 = Frayne, Douglas 1990. Old Babylonian Period (2003-1595 BC). The Royal Inscriptions of Mesopotamia: Early Periods. Vol 4. Toronto \& Buffalo \& London: University of Toronto Press.

Sazonov, Vladimir 2007. Vergöttlichung der Könige von Akkade. Beihefte zur Zeitshrift für alttestamentliche Wissenschaft 374, lk 325-342.

Sazonov, Vladimir 2008. Kuningas Šulgi laul: mõned märkused uus-sumeri kuninga Šulgi (2093-2046) kuningavõimu ideoloogia kohta. Usuteaduslik Ajakiri 57/1, lk 84-107 (https://usuteadus.ee/wp-content/uploads/2008\%20(57)/Sazonov.pdf - 5. august 2020).

Sazonov, Vladimir 2015. Mesopotaamia kuningate universalistlikud taotlused ja jumalik päritolu Varadünastilisel ja Akkadi perioodil. Usuteaduslik Ajakiri 68/1, lk 152-181 (https://usuteadus.ee/wp-content/uploads/2015_1\%20(68)/Sazonov.pdf-5. august 2020).

Sazonov, Vladimir 2016a. Universalistic Ambitions and Claims of Divine Origin of Sumerian and Akkadian Rulers. Alter Orient und Altes Testament 390/4, lk 30-61.

Sazonov, Vladimir 2016b. Die Assyrischen Königstiteln und -epitheta vom Anfang bis Tukulti-Ninurta I und seinen Nachfolgern. USA. Winona Lake: Eisenbrauns.

Sazonov, Vladimir 2018. Universalistic Ambitions, Deification and Claims of Divine Origin of Mesopotamian Rulers II: Lagaš II Dynasty. Usuteaduslik Ajakiri 72/1, lk 42 58 (https://usuteadus.ee/wp-content/uploads//2018_1\%20(72)/Vladimir-Sazonov.pdf 5. august 2020).

Sazonov, Vladimir 2019. Some Notes on the King of The Four Corners. N.A.B.U. 3, lk 102-105.

Sazonov, Vladimir \& Espak, Peeter \& Johandi, Andreas 2015. Vana-Lähis-Ida ajalugu 3500-2000 eKr. Mesopotaamia ajalugu kiilkirja tekkest kuni Uus-Sumeri riigi languseni. Tartu: Tartu Ülikooli Kirjastus.

Selz, Gebhard J. 1998. Über Mesopotamische Herrschaftskonzepte. Zu den Ursprüngen mesopotamischer Herrscherideologie im 3. Jahrtausend. Dietrich, Manfried \& Loretz, 
Oswald (toim). Dubsar anta-men. Studien zur Altorientalistik. Festschrift für Willem H. Ph. Römer zur Vollendung seines 70. Lebensjahr mit Beiträgen von Freunden, Schülern und Kollegen, Münster: Ugarit-Verlag, lk 281-343.

Selz, Gebhard J. 2008. The Divine Prototypes. Brisch, Nicole (toim). Religion and Power: Divine Kingship in the Ancient World and Beyond. Oriental Institute Seminars 4. Chicago: The Oriental Institute of the University of Chicago, lk 13-31.

Seux, Marie-Jean 1965. Les titres royaux 'šar kiššati' et 'šar kibrāt arba'i'. Revue D'Assyriologie et D'Archéologie Orientale 59, lk 1-18.

Seux, Marie-Jean 1967. Épithètes royales akkadiennes et sumériennes. Ouvrage publié avec le concours du Centre National de la Recherche Scientifique. Paris: Letouzey et Ané.

Simkó, Krisztián 2013. Bemerkungen zu Lipiteštar A Z. 87. N.A.B.U. 4 (71), lk 115-118.

Vacín, Luděk 2009. On the Solar Aspect of the King in Ur III Royal Ideology. Chatreššar 2009. International Journal for Indo-European, Semitic, and Cuneiform Languages. Poříčany: Charles University in Prague, Faculty of Arts, lk 171-179.

Vacín, Ludek 2011. Šulgi of Ur: Life, Deeds, Ideology and Legacy of Mesopotamian Rulers As Reflected Primarily In Literary Texts. Thesis submitted for the degree of $\mathrm{PhD}$ in Assyriology. Department of the Languages and Cultures of Near and Middle East, School of Oriental and African Studies University of London, London.

\section{Summary}

\section{Some remarks on the King of the Four Corners and the God-King in ancient Sumer and Akkad in the 3rd millennium BCE}

\section{Vladimir Sazonov}

Senior Research Fellow in Ancient Near Eastern Studies

Centre for Oriental Studies, University of Tartu, Estonia

Senior Research Fellow, Estonian Military Academy

sazonov@ut.ee

Keywords: Akkad, deification, God-King, King of the Four Corners, King of the Universe, Mesopotamia, Sumer

This article is dedicated to the issues related to the King of the Four Corners and the God-King in ancient Sumer and Akkad in the 3rd millennium BCE. The author shows that the title King of the Four Corners has always deified the ruler, but the ruler who used the title King of the Universe never claimed divinity.

What conclusions can we draw?

Except in two cases - the case of Erri-dupizir and the case of Utu-hegal - all kings who used the title king of the four corners were deified. 
Erri-dupizir was a foreigner, more a warlord or tribal chief of the Gutians than a king, but he tried to legitimate his power by using Akkadian-Sumerian formulas, among them royal titles.

Utu-hegal freed Sumer from the Gutians' yoke and re-introduced old Sumero-Akkadian ideological elements, among them the king of the four corners, because he wanted to be as powerful and strong as the Akkadian king Narām-Su'en, who was an example for Utu-hegal. We do not have any proof regarding the deification of Utu-hegal, as he ruled only 6-7 years, and we have only a few texts from the time of his reign.

More interesting is the fact that none of the Sumerian or Akkadian kings who used the title king of the universe in the 3rd millennium and even in the early 2nd millennium BCE (Isin-Larsa period) were deified (at least we do not have a firm proof). How to explain this phenomenon?

Firstly, I think the title king of the four corners had a slightly different meaning than king of the universe; however, both are universalistic titles. The title king of the four corners was probably seen as a wider and more important universalistic title in the sense not only of universal rule, but also of ruling the divine universe and divine spheres (heaven, sun, stars, etc.). It seems that it included some kind of divine aspect, while at least the Sumerian version of the title lugal an-ubda-limmuba means "king of the heaven's four corners".

The title king of the four corners was related to the universe order, to the sun and the cosmos, and to cosmic divine powers, and they were connected to the universal order. We can see that sometimes the title king of the four corners was used to refer to gods in Ancient Mesopotamia - for example in the case of the god Tišpak in Ešnunna - but never king of the universe.

Secondly, early dynastic rulers (e.g. Lagash or Uruk), who never used universalistic titles for themselves, addressed universalistic expressions and epithets to the main gods - e.g., Enlil, Ningirsu, etc. For example, Lugal-kiğine-dudu of Uruk claimed: "Enlil, king of all lands, for Lugal-kiğine-dudu - when the god Enlil truly summoned him, and (Enlil) combined (both) lordship and kingship for him". ${ }^{9}$

Thirdly, ruling over all the lands from east to west or over the corners of the universe - these epithets may be used for gods. LUGAL KIŠ (later Akkadian šar kiššati $(m)$ ) in its early original meaning was seen only as "ruler over Kiš (or ruler over (the northern part of) Sumer)"; it was an important though more regional and geographic title.

Fourthly, only much later did it acquire the meaning king of the universe but I am not sure about that meaning at all. In that case, king of the four corners had a different meaning; the title designated not only ruling over the world but it probably included some kind of divine aspect as well (Michalowski 2010). In that case the title šar kibrät arba'i $(m)$ - king of the four corners could be seen as more universal than LUGAL KIŠ (šar kiššati $(m))$.

There still remain several questions which need to be solved:

- Was LUGAL KIŠ in its Akkadian form šar kiššati $(m)$ a universalistic title at all?

- Or was LUGAL KIŠ a hegemonic title showing certain hegemonic rule or lordship over (all) Sumer (and Akkad?) but not including the whole world (here: Mesopotamia)?

- Could it be for this reason that the king who used the title king of the four corners had to be deified but the king who was LUGAL KIŠ had not? 
Vladimir Sazonov on Eesti assürioloog. Ta töötab Tartu Ülikoolis vana-LähisIda uuringute vanemteadurina, Eesti Kaitseväe akadeemias vanemteadurina ja Sisekaitseakadeemias teadurina. Ta on õppinud Lähis-Ida ajalugu, täiendanud ennast Göttingenis, Baselis, Moskvas, Istanbulis jm.

Vladimir Sazonov (PhD) an Estonian Assyriologist. He is Senior Research Fellow in Ancient Near Eastern Studies at the University of Tartu, Senior Research Fellow at the Estonian Military Academy, and Research Fellow at the Estonian Academy of Security Sciences. He has studied Near Eastern history and has taken refresher courses in Göttingen, Basel, Moscow, Istanbul, etc.

sazonov@ut.ee 